\title{
QUALITY VERSUS QUANTITY - THE COMPOSITION EFFECT OF CORPORATE TAXATION ON FOREIGN DIRECT INVESTMENT
}

\author{
JOHANNES BECKER \\ CLEMENS FUEST
}

CESIFO WORKING PAPER NO. 2126

CATEgORY 1: Public FinANCE

OCTOBER 2007
An electronic version of the paper may be downloaded
- from the SSRN website:
- from the RePEc website:
- from the CESifo website:
www.SSRN.com
www.RePEc.org
www.CESifo-group.org/wp




\title{
QUALITY VERSUS QUANTITY - THE COMPOSITION EFFECT OF CORPORATE TAXATION ON FOREIGN DIRECT INVESTMENT
}

\begin{abstract}
This paper studies corporate taxation in a model where foreign investment of firms may affect the profitability of the investor firm's domestic activities. In this framework, corporate taxes distort the quality, not just the quantity of foreign direct investment flows. High-tax countries may see their tax revenues decrease in response to inbound foreign direct investment. Our results also imply that empirical studies on international profit shifting may overestimate the role of profit shifting. Observed profitability differences between high and low tax countries may be due to project selection. Empirical evidence in support of the main hypotheses is provided using aggregate investment and tax revenue data from a sample of OECD countries.

JEL Code: H25, F23.
\end{abstract}

Keywords: corporate taxation, foreign direct investment

\author{
Johannes Becker \\ Cologne Center for Public Economics \\ University of Cologne \\ Albertus-Magnus-Platz \\ 50923 Cologne \\ Germany \\ johannes.becker@uni-koeln.de
}

\author{
Clemens Fuest \\ Cologne Center for Public Economics \\ University of Cologne \\ Albertus-Magnus-Platz \\ 50923 Cologne \\ Germany \\ clemens.fuest@uni-koeln.de
}

This version: 5th October 2007

We thank Andreas Haufler, Martin Hellwig, Harry Huizinga, Christian Keuschnigg, Kai Konrad and participants at research workshops in Berlin, Bonn, Munich and Tilburg for very helpful comments. We gratefully acknowledge financial support from the Deutsche Forschungsgemeinschaft (DFG), Grant No. FU 442/3-1. 


\section{Introduction}

Standard models of tax effects on international investment assume that investing abroad has no direct impact on the profitability of domestic activities of the investing firm. ${ }^{1}$ However, there is extensive empirical evidence that investing abroad, be it greenfield investment or mergers and acquisition (m\&a), strongly influences the profitability, productivity, employment etc. of the investor firm. In this paper, we present a simple model which allows for such feedback effects of foreign direct investment on domestic activity. We find that, in the presence of feedback effects, corporate taxes distort the quality, not just the quantity, of foreign direct investment. High tax countries are likely to attract investment projects which yield low profits in the host country and contribute little to its corporate tax revenue whereas low tax countries can expect the opposite. We call this the composition effect of corporate taxation on foreign direct investment.

We provide empirical evidence supporting the main prediction of our model with regard to tax revenues. We find that the contribution of foreign direct investment to tax revenue is positive for low tax countries but declines with increasing tax rates. If the effective average tax rate exceeds approximately 30 per cent, an increase in foreign direct investment reduces corporate tax revenue.

In the literature, the observation that profitability tends to be lower in high tax countries is usually interpreted as reflecting that firms shift book profits to low tax countries. $^{2}$ This paper offers a complementary explanation for tax driven differences in profitability. Our analysis suggests that existing studies may overestimate the importance of profit shifting. This may have important policy implications. We discuss this issue further in section 5 .

In research on international taxation, feedback effects of foreign investment on the investor firm have been neglected completely. In contrast, the literature on multinational firms recognizes their importance and points out that synergies between different firms of a multinational group and complementarities of their assets are an important factor for the formation and the existence of these firms. ${ }^{3}$

\footnotetext{
${ }^{1}$ See the surveys in Haufler (2001), Wilson \& Wildasin (2004), Fuest, Huber \& Mintz (2005) and Devereux (2006).

${ }^{2}$ See e.g. Grubert \& Mutti (1991), Hines \& Rice (1994) and the studies cited in section 5.

${ }^{3}$ See e.g. the introduction to the theory of multinational firms in Markusen (2002), ch. 1.
} 
We define synergies as an increase in profits for the whole group caused by bordercrossing investment. A multinational group will realize an investment project if the after tax profit change for the whole group is at least as high as the cost of capital. The firm is indifferent about where these profits are generated, in the headquarter or in the new production plant. But, from a national tax policy perspective, the distribution of profits across subsidiaries of the multinational firm located in different countries is of key importance. It is the purpose of this paper to analyze the effect of taxes on cross-border investment when the profit change is not restricted to occur in the country of the initial investment.

In principle, there are three possible ways in which a foreign investment project may change the distribution of profits within the multinational group. Firstly, the investment may not affect the profit generated by the parent company in its country of residence, as usually assumed in standard models of international investment. In this case, the marginal investment project has a return equal to the cost of capital. Secondly, the transaction may reduce the profits of the parent company. This may happen, for instance, if a plant built abroad produces a good which competes with a good produced by the parent company. In this case, the project will only be undertaken if it increases the profitability of the subsidiary by more than the cost of capital. Thirdly, the investment project may increase the profits of the parent company. A possible reason could be that the subsidiary provides market access or specific know how to the parent company. In this case, the marginal investment project may imply that profits in the subsidiary are very low or even negative because the higher profits of the parent company make the investment worthwhile.

Recent evidence shows that investment abroad has a significant impact on all types of performance indicators of the parent company, independent of whether investment takes the form of greenfield projects or m\&a. Desai, Foley \& Hines (2005a) find that investment abroad increases the aggregate domestic investment activity by US multinationals. Desai, Foley \& Hines (2005b) use firm-level data of US multinationals and show that foreign investment in plant, property and equipment (PPE) is associated with higher domestic PPE investment. Similarly, Egger \& Pfaffermayer (2003) find that foreign investment increases domestic investment in tangible assets and does not decrease investment in intangibles. Castellani \& 
Barba Navaretti (2004) and Jaeckle (2006) show that going abroad increases domestic productivity and competitiveness. In addition, there are several empirical studies, surveyed by Andrade, Mitchell \& Stafford (2001), analyzing the effects of m\&a on the investor firm's performance. There is empirical evidence that m\&a create efficiency gains which seem to be distributed asymmetrically, though, as e.g. McGuckin \& Nguyen (1995) report. While recently acquired firms experience productivity improvements, the investor firm's plants suffer productivity losses, making the net change for the investor firm essentially zero.

Our main argument is the following. If investment abroad has some effect on the performance of the investor company in the domestic country, then the marginal return generated in the foreign location may differ from the cost of capital. For example, if domestic profits increase, then the marginal foreign investment may even yield negative returns. Given this, taxes affect the selection of border crossing investment projects which are carried out. If a potential host country increases its taxes, it will deter projects which produce high profits in the host country (and low profits or losses in the country where the parent company resides). At the same time, this country will attract more projects which produce low profits or losses in the host country and high profits in the country where the parent company resides. As a result, the quantity of capital imports may increase, decline or remain constant in response to the higher tax. But the quality of inbound investment in the host country as measured by its contribution to the domestic profit tax base will unambiguously deteriorate. This is what we call the composition effect of corporate taxation on cross-border investment.

The composition effect has some important implications. Firstly, the welfare cost of tax distortions may be higher than suggested by studies focusing on the quantity aspect alone. Secondly, as mentioned above, observed tax induced profitability differences may not only be due to the shifting of book profits across countries. Thirdly and more generally, policies which aim at attracting foreign direct investment may have to pay more attention to the qualitative dimension of this investment.

The rest of the paper is set up as follows. In section 2, we present the model. Section 3 discusses some extensions. In section 4 , we provide suggestive evidence for the main hypotheses. Section 5 concludes. 


\section{The model}

In this section, the model setup is presented (2.1) before we derive tax effects on investment quality (2.2). Then, tax rate effects on tax revenues are considered (2.3). Finally, we ask for the optimal tax policy strategy and tax effects on welfare $(2.4)$.

\subsection{Setup}

The world consists of two countries, domestic and foreign. In the domestic country, there is a representative household endowed with $N$ units of capital. Moreover, there are many identical firms which have some ongoing production in the two countries. These firms consider investment projects in the foreign country. Crossborder investment has two effects. Firstly, the project generates profit income (or losses) in the foreign investment location, denoted by $\Phi^{*}$. Henceforth, the asterisk denotes the location in the foreign country. Secondly, the profit of the domestic investor firm generated in its country of residence changes by $\Delta .{ }^{4}$

More formally, each domestic firm $i$ randomly draws a project and then decides whether or not realize it. The project is characterized by a pair $\left(\Delta_{i}, \Phi_{i}^{*}\right)$ of profit changes at the investor's and the investment location. $\Delta, \Phi^{*}$ are two jointly distributed variables $\left(\Delta, \Phi^{*}\right) \in \mathbb{R}^{2}$. For simplicity, we assume that the two variables are uniformly distributed over the intervals $\Delta \in\left\{\Delta^{-}, \Delta^{+}\right\}$and $\Phi^{*} \in\left\{\Phi^{*-}, \Phi^{*+}\right\}$. Each project requires one unit of capital which can be rented at a price of $\rho$ in the world capital market.

Standard models virtually always assume that $\Delta$ is equal to zero. It is the main novelty of this model to allow for profit level changes in the investor firm, i.e. we consider positive, negative or zero values of $\Delta$. In other words, the investment project may effectively increase or decrease profits of the parent company, or it may not affect them at all. If $\Delta<0$, the transaction reduces the profits of the parent company. A possible reason would be that the new subsidiary produces a good which competes with products exported by the parent company. $\Delta>0$,

\footnotetext{
${ }^{4}$ In the following, we will use the terms profit and profit changes equivalently. The term profit is more adequate if new production facilities are established, whereas profit change is more exact if existing production plants are modified, i.e. in the course of an acquisition or merger.
} 
i.e. an increase in profits of the parent company, may occur, for instance, if the subsidiary owns technical knowledge or offers market access which is beneficial to the parent company.

Thus, in the absence of taxes, the profit of a border crossing investment project is:

$$
\Delta+\Phi^{*}-\rho
$$

Denote by $\Phi^{* c}$ the marginal project for a given $\Delta$. In equilibrium, each marginal project will satisfy $\Delta+\Phi^{* c}=\rho$.

Now, taxes are introduced. In our model, profits are subject to corporate income taxes. Foreign source income is exempt from domestic tax, i.e. we assume that international investment income is taxed according to the exemption system. The nontax capital cost is not deductible, i.e. we assume equity financing. Projects are realized if posttax-profits, aggregated over the domestic and the foreign location, are nonnegative, i.e. $\Delta(1-\tau)+\Phi^{*}\left(1-\tau^{*}\right) \geq \rho$, where $\tau$ is the domestic corporate tax rate and $\tau^{*}$ is the corporate tax rate of the foreign country. For each $\Delta$, there is a marginal project which satisfies:

$$
\Phi^{* c}=\frac{\rho}{1-\tau^{*}}-\Delta\left(\frac{1-\tau}{1-\tau^{*}}\right)
$$

Projects with $\Phi^{*}<\Phi^{* c}$ are not realized. The right hand side of (2) may be interpreted as the cost of capital of foreign direct investment. The first term is increasing in $\rho$ and the corporate tax rate of the country where the investment is located. This effect is well known from standard tax models of international investment. The second term on the right hand side of (2) is in the focus of this paper. It reflects that the new foreign investment project may affect the ongoing activity of the multinational firm in its country of residence. If $\Delta>0$, the second term reduces the cost of capital. The reason is that foreign investment increases the profits of the parent company. Accordingly, $\Delta<0$ implies that foreign investment reduces domestic profits, so that the minimum foreign profit required to make the project worthwhile increases.

The foreign country has no capital endowment. It only imports capital and 
taxes profits generated by investment of multinational firms. This asymmetry assumption is made for the following reason. In this setup, investment of multinational firms in the foreign country is the only source of capital demand. Given that the supply of capital is fixed, the quantity of capital exported from the domestic country to the foreign country is given. This allows us to focus on the quality side of capital flows. In section 3.1, we extend the model to allow for changes in both the quality and the quantity of border crossing capital flows.

\subsection{Tax rate effects on investment quality}

Equation (2) shows that taxes may distort investment. In the standard model, with $\Delta=0$, the implications are clearcut. For $\tau>0$, it follows $\Phi^{* c}>\rho$, i.e. the return of the marginal unit of capital invested abroad is lower than the marginal return in the absence of taxes. In contrast, if we allow for $\Delta \neq 0$, the picture may change. For large and positive $\Delta$, the minimum required project returns at the investment location $\Phi^{* c}$ may become negative. This has important consequences for the effect of corporate taxation on investment. Holding $\rho$ constant, a marginal increase of the domestic and foreign corporate tax rate has the following effect on outbound investment:

$$
\frac{\partial \Phi^{* c}}{\partial \tau^{*}}=\frac{\Phi^{* c}}{1-\tau^{*}} \quad \text { and } \frac{\partial \Phi^{* c}}{\partial \tau}=\frac{\Delta}{1-\tau^{*}}
$$

These expressions can be interpreted as follows. A positive sign of the derivative means that a tax rate increase raises the required profit of the foreign investment project. In this case, higher taxes deter investment. Accordingly, negative values represent cases where higher taxes increase investment. Now, consider the standard case with $\Delta=0$. In this case, it follows from equation (2) that $\Phi^{* c}>0$, i.e. the profit change in the foreign country caused by the marginal investment project must be positive. In this case, higher foreign taxes deter investment $\left(\frac{\partial \Phi^{* c}}{\partial \tau^{*}}\right) . \Delta=0$ also implies that domestic corporate taxes do not affect outbound investment, i.e. $\frac{\partial \Phi^{* c}}{\partial \tau}=0$.

This changes if we allow foreign investment to affect the profits of the domestic parent company, i.e. $\Delta \neq 0$. If $\Delta$ is positive and sufficiently large, the profit change at the investment location caused by the marginal project $\left(\Phi^{* c}\right)$ becomes negative, 
i.e. $\Phi^{* c}<0$. In this case, the effect of corporate taxes on investment is reversed: $\frac{\partial \Phi^{* c}}{\partial \tau^{*}}<0$. In other words, higher foreign tax rates c.p. increase investment in the foreign country. The reason is that the after tax cost of the decline in foreign profits caused by the marginal investment project is smaller, the higher the tax rate. The other interesting effect is that corporate taxes in the domestic country may c.p. deter outbound investment. This also occurs if the profit change at the parent company location is positive: $\frac{\partial \Phi^{* c}}{\partial \tau}=\frac{\Delta}{1-\tau^{*}}>0$.

So far, we have discussed the effects of tax changes in our model assuming that the interest rate $\rho$ is constant. But of course, a variation in the tax rate will also change the interest rate $\rho$ in our model. Total tax effects are therefore given by

$$
\frac{d \Phi^{* c}}{d \tau^{*}}=\frac{\Phi^{* c}}{1-\tau^{*}}+\frac{1}{1-\tau^{*}} \frac{d \rho}{d \tau^{*}}
$$

The capital market equilibrium is given by the equation

$$
\int_{\Delta^{-}}^{\Delta^{+}} \int_{\Phi^{* c}\left(\rho, \tau, \tau^{*}\right)}^{\Phi^{*+}} d \Phi^{*} d \Delta=N
$$

Since the supply of capital is fixed, $\rho$ will adjust to tax changes so that overall capital demand remains constant. Total differentiation yields

$$
\frac{d \rho}{d \tau^{*}}=-\frac{\int_{\Delta^{-}}^{\Delta^{+}} \frac{\partial \Phi^{* c}}{\partial \tau^{*}} d \Delta}{\int_{\Delta^{-}}^{\Delta^{+}} \frac{\partial \Phi^{* c}}{\partial \rho} d \Delta}=-\int_{\Delta^{-}}^{\Delta^{+}} \Phi^{* c} d \Delta \equiv-\bar{\Phi}^{* c}
$$

where we have used $\int_{\Delta^{-}}^{\Delta^{+}} d \Delta=1 . \bar{\Phi}^{* c}$ can be interpreted as the average host country profit generated by the marginal projects $\left(\Phi^{* c}\right)$. The total effect of a change in the foreign tax rate on investment is therefore given by

$$
\frac{d \Phi^{* c}}{d \tau^{*}}=\frac{1}{1-\tau^{*}}\left(\Phi^{* c}-\bar{\Phi}^{* c}\right)=-\frac{(1-\tau)}{\left(1-\tau^{*}\right)^{2}}(\Delta-\bar{\Delta})
$$

where $\bar{\Delta} \equiv \int_{\Delta^{-}}^{\Delta^{+}} \Delta d \Delta$ is the average $\Delta$. Equation (7) is of key importance for our analysis. It has the following interpretation. Depending on the value of $\Delta, \Phi^{* c}$ may be larger or smaller than $\bar{\Phi}^{* c}$. Consider first the firms where $\Phi^{* c}>\bar{\Phi}^{* c}$. These are marginal projects where the profit generated in the foreign country is above the 
average of all marginal projects. Accordingly, profits generated by these projects in the domestic country are lower than on average $(\Delta<\bar{\Delta})$. These investment projects will be crowded out by higher foreign taxes $\left(\frac{d \Phi^{* c}}{d \tau^{*}}>0\right)$. They will be replaced by an expansion of projects which generate lower than average profits in the foreign country $\left(\Phi^{* c}<\bar{\Phi}^{* c}\right)$. This substitution of projects which generate high foreign profits by projects which generate lower foreign profits or even losses is what we refer to as the composition effect of corporate taxation on foreign direct investment. While the mere quantity cannot change in our model, the quality of foreign direct investment changes. If a country increases its tax rate, it attracts fewer projects which generate local profits and more project which generate profits somewhere else.

In parallel to equations (4) and (6), we can derive $\frac{d \Phi^{* c}}{d \tau}=\frac{\Delta}{1-\tau^{*}}+\frac{1}{1-\tau^{*}} \frac{d \rho}{d \tau}$ and $\frac{d \rho}{d \tau}=-\int_{\Delta^{-}}^{\Delta^{+}} \Delta d \Delta \equiv-\bar{\Delta}$. The effect of a small increase of the domestic corporate tax rate on outbound investment is then given by

$$
\frac{d \Phi^{* c}}{d \tau}=\frac{1}{1-\tau^{*}}(\Delta-\bar{\Delta})=-\frac{1}{1-\tau}\left(\Phi^{* c}-\bar{\Phi}^{* c}\right)
$$

which can interpreted equivalently. Note that, again, the tax effect of foreign taxes on foreign inbound investment would be zero in the standard model. The reason is that the number of projects is fixed and does not change in response to changes in $\tau^{*}$.

These results can be summarized as

Proposition 1 Composition effect: In the presence of feedback effects of foreign investment on domestic performance, an increase in the corporate tax rate changes the quality of investment projects. If the overall number of projects is fixed, an increase in foreign taxes leads to a decline in investment in the foreign country with above average foreign profitability $\left(\Phi^{* c}>\bar{\Phi}^{* c}\right)$ and an increase in investment with below average foreign profitability $\left(\Phi^{* c}<\bar{\Phi}^{* c}\right)$. An increase in the domestic tax rate has the opposite effect.

Figure 1 illustrates the effects of corporate taxation on investment decisions in our model, seen from the perspective of a high-tax country, i.e. assuming that $\tau>\tau^{*}$. 

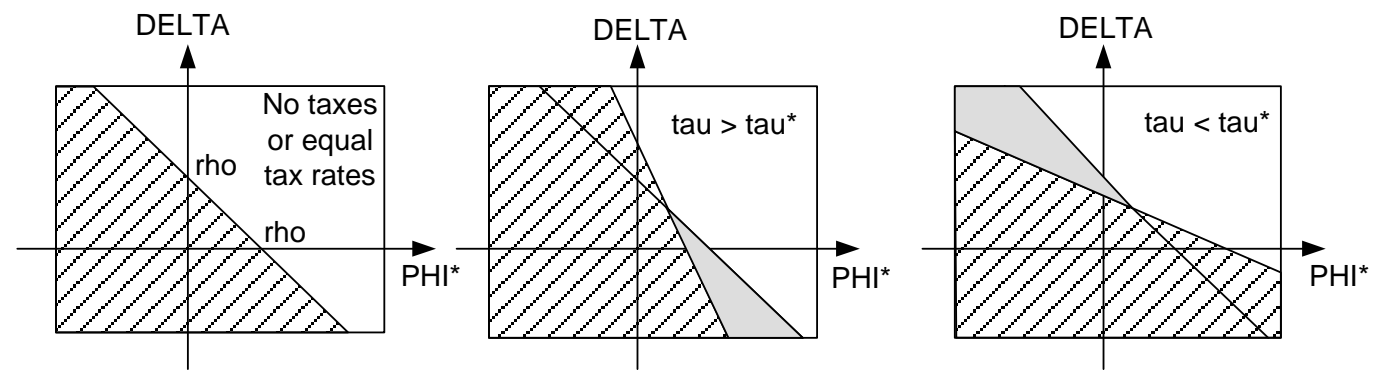

Figure 1: Tax effects on international investment.

The lines that separate the hatched area from the blank one show the locus of marginal investment as a function of different values for $\Delta$ and $\Phi^{*}$. Consider first the case without taxes, depicted on the left hand side of the figure. At the margin, $\Phi^{* c}=\rho$ if $\Delta=0$, and $\Delta=\rho$ if $\Phi^{* c}=0$. The slope of the curve is given by $\frac{d \Delta}{d \Phi^{* c}}=-1$. All transactions above the line will be realized whereas possible investment projects in the shaded area are rejected.

The graph in the center of figure 1 illustrates the space of feasible investment in the presence of taxes assuming $\tau>\tau^{*}$. Note that, if both tax rates $\tau$ and $\tau^{*}$ are equal, $\rho$ adjusts until all capital is employed. Then, the graph is the same as on the left hand side with points of intersection $\frac{\rho}{1-\tau}, \frac{\rho}{1-\tau^{*}}$. For $\tau \neq \tau^{*}$, though, the points of intersection with the $\mathrm{x}$ - and the $\mathrm{y}$-axis are shifted according to equation (2). The slope of the marginal investment curve becomes steeper, $\frac{d \Delta}{d \Phi^{* c}}=-\frac{1-\tau^{*}}{1-\tau}<-1$. Corporate taxes now have two effects: The first is that projects are not realized any more in the low-tax country that would have been in the absence of taxes (hatched area above the no-tax-line). But, in addition, some projects are now realized that would not have been without taxes (shaded area beneath the no-tax-line). These projects are characterized by high positive profit changes in the foreign country and negative profit changes in the domestic high-tax country. The graph on the right hand side shows the case of $\tau<\tau^{*}$. The slope of the marginal investment line is flatter now, $\frac{d \Delta}{d \Phi^{* c}}>-1$. There are some projects (high $\Phi^{*}$, low $\Delta$ ) which are not realized anymore and some projects realized which were rejected in the absence of taxes (low $\Phi^{*}$, high $\Delta$ ). 


\subsection{Tax rate effects on tax revenue}

What are the effects of tax rate increases on tax revenue if the quality dimension matters? Before we derive these effects in our model, recall the standard model. An increase in corporate tax rates has essentially two effects. It increases revenue by raising the tax burden for each project, and it decreases revenue by lowering the number of projects carried out. These countervailing effects generate the typical shape of the Laffer-curve which has a maximum at the revenue-maximizing tax rate. But if the number of projects is fixed, there is no countervailing effect in the standard model, since there is no qualitative dimension, and the revenuemaximizing tax rate would be $\tau=100 \%$.

In our model, the tax revenue of the foreign, capital importing country is given by

$$
T^{*}=\tau^{*} B^{*}=\tau^{*} \int_{\Delta^{-}}^{\Delta^{+}} \int_{\Phi^{* c}}^{\Phi^{*+}} \Phi^{*} d \Phi^{*} d \Delta
$$

where $B^{*}$ denotes the tax base. A small increase in the corporate tax rate $\tau^{*}$ has the following effect: $d T^{*}=d \tau^{*} B^{*}+\tau^{*} d B^{*}=\left(B^{*}+\tau^{*} \frac{\partial B^{*}}{\partial \tau^{*}}\right) d \tau^{*}+\tau^{*} \frac{\partial B^{*}}{\partial \rho} d \rho$. $d B^{*}$ can be expressed as

$$
d B^{*}=-\int_{\Delta^{-}}^{\Delta^{+}} \frac{\partial \Phi^{* c}}{\partial \tau^{*}} \Phi^{*} d \Delta d \tau^{*}-\int_{\Delta^{-}}^{\Delta^{+}} \frac{\partial \Phi^{* c}}{\partial \rho} \Phi^{*} d \Delta d \rho
$$

Using equation (6), it follows:

$$
\frac{d B^{*}}{d \tau^{*}}=-\frac{1}{1-\tau^{*}} \operatorname{var}\left(\Phi^{* c}\right)<0
$$

where $\operatorname{var}\left(\Phi^{* c}\right)$ is the variance of $\Phi^{* c} .^{5}$ In the standard model, there is no qualitative dimension of investment, and therefore $\operatorname{var}\left(\Phi^{* c}\right)=0$. In this model, where $\operatorname{var}\left(\Phi^{* c}\right)>0$, an increase in the foreign tax rate decreases the foreign tax base because of the composition effect, i.e. because the tax increase leads to a substitution of investment projects with a high local profitability by projects with

${ }^{5}$ The variance is given by $\operatorname{var}\left(\Phi^{* c}\right)=\int_{\Delta^{-}}^{\Delta^{+}} \Phi^{* c 2} d \Delta-\left(\int_{\Delta^{-}}^{\Delta^{+}} \Phi^{* c} d \Delta\right)^{2}$. 
lower profits. The effect of the tax increase on foreign tax revenue is

$$
\frac{d T^{*}}{d \tau^{*}}=B^{*}-\frac{\tau^{*}}{1-\tau^{*}} \operatorname{var}\left(\Phi^{* c}\right)
$$

Consider next the effect of an increase in the domestic tax rate on tax revenue in the foreign country. The derivation is analogous and yields

$$
\frac{d T^{*}}{d \tau}=-\frac{\tau^{*}}{1-\tau^{*}} \operatorname{cov}\left(\Delta, \Phi^{* c}\right)
$$

where $\operatorname{cov}\left(\Delta, \Phi^{* c}\right)$ is the covariance of $\Delta$ and $\Phi^{* c} .{ }^{6}$ Equation (2) implies that the covariances are negative. Therefore, an increase in the domestic tax rate increases foreign tax revenue: $\frac{d T^{*}}{d \tau}>0$. In the same way, we can derive the effects of tax changes on domestic tax revenue. The impact of a change in the domestic tax rate is

$$
\frac{d T}{d \tau}=B-\frac{\tau}{1-\tau^{*}} \operatorname{var}(\Delta)
$$

where $\operatorname{var}(\Delta)$ is the variance of $\Delta .^{7}$ A change in the foreign tax rate yields

$$
\frac{d T}{d \tau^{*}}=-\frac{\tau}{1-\tau^{*}} \operatorname{cov}\left(\Delta, \Phi^{* c}\right)
$$

These results may be summarized as

Proposition 2 An increase in the foreign tax rate unambiguously reduces the foreign tax base and increases the domestic tax base (and vice versa), although the number of projects remains constant.

The unambiguously negative effect of a tax increase on the domestic tax base is due to the composition effect of corporate taxation. The tax increase encourages investment projects which produce losses and discourages profitable projects.

This effect of investment on tax revenue is one of the empirically testable implications of our model. If our model actually explains part of real world investment flows then we should observe that high-tax countries have less gain from inbound

\footnotetext{
${ }^{6}$ The covariance is given by $\operatorname{cov}\left(\Delta, \Phi^{* c}\right)=\int_{\Delta^{-}}^{\Delta^{+}} \Delta \Phi^{* c} d \Phi^{*} d \Delta-\left(\int_{\Delta^{-}}^{\Delta^{+}} \Phi^{* c} d \Delta\right)\left(\int_{\Delta^{-}}^{\Delta^{+}} \Delta d \Delta\right)$.

${ }^{7}$ The variance is given by $\operatorname{var}(\Delta)=\int_{\Delta^{-}}^{\Delta^{+}} \Delta^{2} d \Delta-\left(\int_{\Delta^{-}}^{\Delta^{+}} \Delta d \Delta\right)^{2}$.
} 
investment in terms of tax revenue than low-tax countries. In section 4, we test this hypothesis empirically. We find that the higher the tax rate the lower is the additional tax revenue per unit of foreign direct investment. Above a certain level of the tax rate the contribution of FDI to tax revenues even becomes negative.

\subsection{Optimal tax policy and welfare}

In this section, we derive the optimal tax policy of the doemstic and the foreign country. In both countries, the governments maximize the welfare of a representative household. Consider first the domestic country. The welfare of the domestic household $(W)$ is assumed to depend on private consumption $C$ and publicly provided goods $G$ : $W=W(C, G)$. To ease notation, we assume $W=C+H(G)$. Private consumption is given by the private return to investment

$$
C=\rho N+\int_{\Delta^{-}}^{\Delta^{+}} \int_{\Phi^{* c}}^{\Phi^{*+}}\left[\Delta(1-\tau)+\Phi^{*}\left(1-\tau^{*}\right)-\rho\right] d \Phi^{*} d \Delta
$$

Since the entire capital stock and all firms belong to the domestic household (16) boils down to

$$
C=\int_{\Delta^{-}}^{\Delta^{+}} \int_{\Phi^{* c}}^{\Phi^{*+}}\left[\Delta(1-\tau)+\Phi^{*}\left(1-\tau^{*}\right)\right] d \Phi^{*} d \Delta
$$

$G$ is financed by corporate tax revenues only. Domestic welfare is given by

$$
W=\int_{\Delta^{-}}^{\Delta^{+}} \int_{\Phi^{* c}}^{\Phi^{*+}}\left[\Delta(1-\tau)+\Phi^{*}\left(1-\tau^{*}\right)\right] d \Phi^{*} d \Delta+H\left(\tau \int_{\Delta^{-}}^{\Delta^{+}} \int_{\Phi^{* c}}^{\Phi^{*+}} \Delta d \Phi^{*} d \Delta\right)
$$

The effect of a small increase in $\tau$ on domestic welfare is given by $\frac{d W}{d \tau}=$ $\frac{\partial W}{\partial \tau}+\frac{\partial W}{\partial \rho} \frac{d \rho}{d \tau}$. After some rearrangements, presented in the appendix, it follows

$$
\frac{d W}{d \tau}=\left(H^{\prime}-1\right) \int_{\Delta^{-}}^{\Delta^{+}} \int_{\Phi^{* c}}^{\Phi^{*+}} \Delta d \Phi^{*} d \Delta-H^{\prime} \frac{\tau}{1-\tau^{*}} \operatorname{var}(\Delta)
$$

The optimal tax policy involves the following tradeoff: The first term on the right hand side of (19) reflects that a higher tax rate shifts income from the domestic household to the government. This increases welfare if the marginal util- 
ity from public consumption exceeds the marginal utility of private consumption $H^{\prime}-1>0$. The second term is unambiguously negative if the tax rate is positive and reflects that a tax rate increase reduces the tax base. This trade-off is familiar from standard models of tax policy in models with capital mobility. The difference is that the tax base effect results from a change in the quality of investment, ratehr than the quantity.

How does an increase in the foreign tax rate affect domestic welfare? The welfare effect is given by $\frac{d W}{d \tau^{*}}=\frac{\partial W}{\partial \tau^{*}}+\frac{\partial W}{\partial \rho} \frac{\partial \rho}{\partial \tau^{*}}$ which can be rearranged (see appendix) to

$$
\frac{d W}{d \tau^{*}}=-\int_{\Delta^{-}}^{\Delta^{+}} \int_{\Phi^{* c}}^{\Phi^{*+}} \Phi^{*} d \Phi^{*} d \Delta-H^{\prime} \frac{\tau}{1-\tau^{*}} \operatorname{cov}\left(\Delta, \Phi^{* c}\right)
$$

The first term on the r.h.s. of (20) is negative and reflects that an increase in the foreign tax reduces the profit income of domestic households. ${ }^{8}$ The second term is unambiguously positive. It represents the positive fiscal externality of a foreign tax rate increase on domestic tax revenue. The overall welfare effect is ambiguous.

The foreign country maximizes revenue from taxing firms. It benefits from an increase in domestic taxes. It is beyond the scope of this paper to fully analyze tax competition in the presence of quality aspects of investment. However, it is clear that the scope and the direction of potential coordination policies depends on the fiscal externalities mentioned above. The fiscal externalities are similar to those in the standard model.

\section{Extension: Cross-border investment with qual- ity and quantity dimensions}

So far, we have assumed that the number of projects realized by domestic investors in the foreign country is fixed. We now relax this assumption by introducing a world capital market with an exogenously given interest rate of $r$. Firms may use the rented capital to finance cross-border investment projects. This implies that

\footnotetext{
${ }^{8}$ From the viewpoint of the foreign government, the domestic ownership of foreign assets may imply the incentive to overtax corporate profits, see Huizinga \& Nielsen (1997).
} 
the marginal project is defined as yielding a return which equals the world interest rate $r$ :

$$
\Phi^{* c}\left(1-\tau^{*}\right)+\Delta(1-\tau)=r
$$

Assuming that the interest rate does not react to tax changes, tax effects are given by

$$
\frac{\partial \Phi^{* c}}{\partial \tau^{*}}=\frac{\Phi^{* c}}{1-\tau^{*}} \quad \text { and } \quad \frac{\partial \Phi^{* c}}{\partial \tau}=\frac{\Delta}{1-\tau^{*}}
$$

Aggregate investment, i.e. the overall number investment projects realized in the foreign country $\left(K^{*}\right)$, is now endogenously determined and equal to:

$$
K^{*}=\int_{\Delta^{-}}^{\Delta} \int_{\Phi^{* c}}^{\Phi^{*+}} d \Phi^{*} d \Delta
$$

At a given interest rate in the world capital market, a marginal increase in the foreign corporate tax rate has the following effect on aggregate investment:

$$
\frac{\partial K^{*}}{\partial \tau^{*}}=-\int_{\Delta^{-}}^{\Delta} \frac{\partial \Phi^{* c}}{\partial \tau^{*}} d \Delta=-\frac{\bar{\Phi}^{* c}}{1-\tau^{*}}
$$

The tax effect on investment depends on an expression, $\bar{\Phi}^{* c}=\int_{\Delta^{-}}^{\Delta} \Phi^{* c} d \Delta$, which can be interpreted as the mean marginal profit generated by foreign investment in the foreign country. In the standard model, this expression is equal to $\frac{\partial K^{*}}{\partial \tau^{*}}=-\frac{r}{\left(1-\tau^{*}\right)^{2}}$ since $\Delta$ is assumed to be zero and therefore $\Phi^{* c}$ is equal to $\frac{r}{1-\tau^{*}}$. In our model, though, the expression can be negative. In this case higher taxes increase inbound investment, seen from the foreign government's perspective. The possibility that higher taxes may attract additional investment is due to the fact that the value of losses is higher with high tax rates. If projects with negative marginal profits dominate, an increase in the corporate tax rate increases the value of these projects and leads to an increase in total investment.

Thus, we may state that the qualitative aspects of investment may dominate the quantitative side. In the case of $\int_{\Delta^{-}}^{\Delta} \Phi^{* c} d \Delta=0$, tax rate variations do not change the number of projects at all (although the number of projects is endogenously determined), but they have a composition effect, i.e. they change the qualitative dimension of investment flows. 
What are the effects on tax revenue if we allow for the quantitative dimension of investment? Tax revenue is given by

$$
T^{*}=\tau^{*} B^{*}=\tau^{*} \int_{\Delta^{-}}^{\Delta^{+}} \int_{\Phi^{* c}}^{\Phi^{*+}} \Phi^{* c} d \Phi^{*} d \Delta
$$

where $B$ is the tax base. In the standard model, the effect of a small increase of the corporate tax rate on the tax base is negative because higher tax rates reduce the capital stock. In our model, the effect is given by

$$
\frac{\partial T^{*}}{\partial \tau^{*}}=B^{*}-\frac{\tau^{*}}{1-\tau^{*}} \int_{\Delta^{-}}^{\Delta^{+}} \Phi^{* c 2} d \Delta
$$

Thus, although a higher tax may increase or decrease the foreign capital stock, the effect of a higher foreign tax rate on the tax base is unambiguously negative. The first term on the right hand side is the revenue increasing effect of increasing the tax rate with a given tax base. The second term denotes the tax rate effect on the tax base which is negative.

These results may be summarized as

Proposition 3 An increase in the foreign tax rate may increase or decrease aggregate investment in the foreign country but always reduces the foreign corporate income tax base.

\section{Empirical analysis}

In this section, we provide some suggestive evidence for the relevance of the composition effect of corporate taxation on FDI. It seems that, fortunately, there is already a large number of papers which may be interpreted as providing evidence for the existence of the composition effect and the qualitative dimension of FDI. The empirical literature on tax effects on profit shifting usually starts from the observation that the returns per unit of capital (our $\Phi$ and $\Delta$ ) differ between domestic and foreign affiliates within a multinational company, and that the difference depends on the tax rate differential between the two jurisdictions. These contributions implicitely assume that, besides profit shifting, capital returns in 
the domestic and the foreign affiliate do not depend on each other. This is a very strong assumption. If foreign investment projects have feedback effects on domestic profits, then the observed effects may arise even in the absence of profit shifting.

If investment has a qualitative dimension, high tax countries will be more likely than low tax countries to attract investment projects which lead to low or zero tax payments (or even negative tax payments when the losses can be set against other income). In the following, we therefore measure the impact of FDI on tax revenue. The above presented model predicts that high-tax countries will attract FDI that increases their tax revenues less than FDI in low-tax countries does. We will estimate an equation of the following form:

$$
\text { Tax base }=\alpha_{0}+\alpha_{1} \text { Tax rate }+\alpha_{2} F D I+\alpha_{3} F D I \times \text { Tax rate }+\sum \alpha_{j} X+\varepsilon
$$

If there is a composition effect on FDI, a higher tax rate will lower the increase in tax revenue per unit of incoming FDI or even decrease it in absolute terms. That means that the model predicts a negative estimated coefficient $\alpha_{3}$. Note that in the standard model taxes decrease the quantity of FDI. But when the quantity is controlled for, there is no prediction for the sign or the size of $\alpha_{3}$. Note further that the model yields symmetric predictions for inbound and outbound FDI. Both directions of investment should have a negative estimate of $\alpha_{3}$.

Table 1 shows the summary statistic of the main variables used for estimation. It reports the number of observations, the mean, the standard deviation and the median value.

\begin{tabular}{lrrrr}
\multicolumn{5}{l}{ Table 1: Summary statistic } \\
\hline \multicolumn{7}{l}{ No. obs. } & Mean & St.dev. & Median \\
\hline EATR & 468 & 0.3052 & 0.0685 & 0.2800 \\
Tax rate & 479 & 0.4082 & 0.0924 & 0.3900 \\
Tax revenue & 388 & 0.0302 & 0.0144 & 0.0285 \\
Tax base & 368 & 0.0802 & 0.0734 & 0.0441 \\
Corporate VA & 235 & 0.5534 & 0.0796 & 0.5639 \\
Gross operating surplus & 304 & 0.1981 & 0.0358 & 0.2003 \\
Inbound FDI & 398 & 0.1859 & 0.1696 & 0.1413 \\
Outbound FDI & 392 & 0.2432 & 0.3060 & 0.1444 \\
GDP & 405 & $1,154,263$ & $1,924,153$ & 373,573 \\
\hline Note: Data sources are given in the text. & & &
\end{tabular}

All numbers represent shares of GDP except for tax rates and GDP itself. The 
EATR and the (statutory) tax rates are taken from the IFS corporate tax database described in Devereux, Griffith \& Klemm (2002). For countries not included in the IFS database we added tax rates from KPMG (2006). The tax revenue figures are taken from the OECD database, as well as the share of corporate value added and the gross operating surplus. The tax base is calculated by dividing tax revenues through statutory tax rates. Since this is no perfect measure, we run regression for both tax bases and revenues. Inbound and outbound FDI are provided by UNCTAD. It would be useful to have FDI-weighted investor country tax rates. Unfortunately, it turns out that the share of FDI for which we have tax rate data is too low to construct reliable indicators. Therefore, our estimations are based on the assumption that the host tax rates are a good measure for the (relative) tax burden. This is necessarily true in the aggregate but it may generate biases for individual countries.

Table 1 reports the results of five different estimation specifications. All specifications use host country fixed effects and year fixed effects. In column 1, regression results of equation (27) are presented with the FDI term split in inbound and outbound FDI stocks. As expected, the gross operating surplus has high predictive power for the size of the tax base. The inbound and outbound terms are not significant. However, their coefficients show the same signs and the same structure. Whereas inbound and outbound FDI have a positive coefficient, the interaction terms are negative. Since both inbound and outboud FDI are highly correlated the lack of significance is potentially due to collinearity. Since our model yields symmetric predictions for both directions of FDI, i.e. both incoming and outgoing FDI are supposed to have negative interaction terms with the EATR (or other tax indicator), we go on by using total FDI which is the sum of the two variables. 
Table 2: Regression results

\begin{tabular}{|c|c|c|c|c|c|c|c|c|}
\hline & (1) & & (2) & (3) & (4) & (5) & (6) & (7) \\
\hline & \multicolumn{6}{|c|}{ Tax base } & \multicolumn{2}{|c|}{ Tax revenue } \\
\hline & EATR & & EATR & EATR & EATR & Stat. tax rate & EATR & Stat. tax rate \\
\hline$\overline{\text { EATR }}$ & 0.0872 & & 0.0841 & 0.2718 & 0.1865 & & 0.0291 & \\
\hline & $(0.0659)$ & & $(0.0617)$ & $(0.2403)$ & $(0.1924)$ & & $(0.0868)$ & \\
\hline Statutory tax rate & & & & & & $\begin{array}{l}0.5511 \\
(0.1659)^{\star \star}\end{array}$ & & $\begin{array}{l}0.1595 \\
(0.0545)^{\star \star}\end{array}$ \\
\hline Corporate VA & $\begin{array}{l}-0.2479 \\
(0.1883)\end{array}$ & & $\begin{array}{l}-0.2619 \\
(0.1593)\end{array}$ & $\begin{array}{l}-0.0305 \\
(0.1597)\end{array}$ & & $\begin{array}{l}0.0041 \\
(0.1560)\end{array}$ & $\begin{array}{l}-0.0827 \\
(0.0526)\end{array}$ & $\begin{array}{l}-0.0363 \\
(0.0541)\end{array}$ \\
\hline Corp VA x TR & & & & $\begin{array}{l}-0.0000 \\
(0.0000)^{\star *}\end{array}$ & & $\begin{array}{l}-0.0000 \\
(0.0000)^{\star \star}\end{array}$ & $\begin{array}{l}-0.0000 \\
(0.0000)^{\star \star}\end{array}$ & $\begin{array}{l}-0.0000 \\
(0.0000)^{\star *}\end{array}$ \\
\hline $\begin{array}{l}\text { Gross operating } \\
\text { surplus }\end{array}$ & $\begin{array}{l}0.8913 \\
(0.1795)^{\star \star}\end{array}$ & & $\begin{array}{l}0.9336 \\
(0.1321)^{\star *}\end{array}$ & $\begin{array}{l}1.2679 \\
(0.3146)^{\star \star}\end{array}$ & $\begin{array}{l}1.0510 \\
(0.2827)^{\star \star}\end{array}$ & $\begin{array}{l}1.6395 \\
(0.3168)^{\star \star}\end{array}$ & $\begin{array}{l}0.2238 \\
(0.1060)^{\star}\end{array}$ & $\begin{array}{l}0.3898 \\
(0.0966)^{\star \star}\end{array}$ \\
\hline GOS $\times$ TR & & & & $\begin{array}{l}-1.5318 \\
(0.9854)\end{array}$ & $\begin{array}{l}-1.2175 \\
(0.9308)\end{array}$ & $\begin{array}{l}-2.4204 \\
(0.7098)^{\star \star}\end{array}$ & $\begin{array}{l}0.2917 \\
(0.3599)\end{array}$ & $\begin{array}{l}-0.3233 \\
(0.2356)\end{array}$ \\
\hline Inbound FDI & 0.2571 & & & & & & & \\
\hline & $(0.2215)$ & Total FDI & 0.2474 & 0.1930 & 0.1859 & 0.1724 & 0.0532 & 0.0453 \\
\hline $\begin{array}{c}\text { Inbound FDI } \\
\text { x TR }\end{array}$ & $\begin{array}{l}-0.9970 \\
(0.8369)\end{array}$ & & $(0.0466)^{\star *}$ & $(0.0451)^{\star *}$ & $(0.0416)^{\star \star}$ & $(0.0423)^{\star \star}$ & $(0.0138)^{\star \star}$ & $(0.0127)^{\star \star}$ \\
\hline Outbound FDI & $\begin{array}{l}0.1599 \\
(0.1596)\end{array}$ & $\begin{array}{l}\text { Total FDI } \\
\text { x TR }\end{array}$ & $\begin{array}{l}-0.8159 \\
(0.1726)^{\star \star}\end{array}$ & $\begin{array}{l}-0.6275 \\
(0.1636)^{\star \star}\end{array}$ & $\begin{array}{l}-0.6106 \\
(0.1515)^{\star \star}\end{array}$ & $\begin{array}{l}-0.4787 \\
(0.1213)^{\star \star}\end{array}$ & $\begin{array}{l}-0.1795 \\
(0.0515)^{\star \star}\end{array}$ & $\begin{array}{l}-0.1239 \\
(0.0384)^{\star \star}\end{array}$ \\
\hline $\begin{array}{l}\text { Outbound FDI } \\
\quad \times \text { TR }\end{array}$ & $\begin{array}{l}-0.4401 \\
(0.6538)\end{array}$ & & & & & & & \\
\hline GDP & $\begin{array}{l}0.0000 \\
(0.0000)\end{array}$ & & $\begin{array}{l}0.0000 \\
(0.0000)\end{array}$ & $\begin{array}{l}-0.0000 \\
(0.0000)\end{array}$ & $\begin{array}{l}-0.0000 \\
(0.0000)^{\star \star}\end{array}$ & $\begin{array}{l}0.0000 \\
(0.0000)\end{array}$ & $\begin{array}{l}0.0000 \\
(0.0000)\end{array}$ & $\begin{array}{l}0.0000 \\
(0.0000)^{\star \star}\end{array}$ \\
\hline GDP $\times$ TR & & & & $\begin{array}{l}0.0000 \\
(0.0000)^{\star \star}\end{array}$ & $\begin{array}{l}0.0000 \\
(0.0000)^{\star \star}\end{array}$ & $\begin{array}{l}0.0000 \\
(0.0000)^{\star \star}\end{array}$ & $\begin{array}{l}0.0000 \\
(0.0000)^{\star \star}\end{array}$ & $\begin{array}{l}0.0000 \\
(0.0000)^{\star}\end{array}$ \\
\hline Constant & $\begin{array}{l}0.0199 \\
(0.0883)\end{array}$ & & $\begin{array}{l}0.0180 \\
(0.0820)\end{array}$ & $\begin{array}{l}-0.1466 \\
(0.1095)\end{array}$ & $\begin{array}{l}-0.1230 \\
(0.0598)^{\star}\end{array}$ & $\begin{array}{l}-0.2741 \\
(0.1117)^{\star}\end{array}$ & $\begin{array}{l}0.0115 \\
(0.0361)\end{array}$ & $\begin{array}{l}-0.0601 \\
(0.0364)\end{array}$ \\
\hline Observations & 215 & & 215 & 215 & 283 & 226 & 215 & 226 \\
\hline No. of countries & 15 & & 15 & 15 & 18 & 16 & 15 & 16 \\
\hline R-squared & 0.72 & & 0.72 & 0.74 & 0.71 & 0.76 & 0.63 & 0.64 \\
\hline
\end{tabular}

And, indeed, using the sum of FDI instead of inbound and outbound FDI separately yields significant coefficient estimates for the FDI term which similar properties compared to the estimations reported in column 1. The coefficients have the expected signs: In general, foreign direct investment increases the tax base. However, high-tax countries gain less tax base or even lose some fraction of the tax base. The control variables remain virtually the same and also the R-squared does not decrease.

It may be that the coefficient estimates for the FDI terms are artefacts if hightax countries differ systematically from low-tax countries with regard to other variables. In column 3, we therefore add interaction terms with the EATR for the 
control variables. The FDI coefficients are slightly decreased but remain strongly significant.

How should the results be interpreted? The estimation reported in column 3 suggests that a marginal increase in FDI has the following effect on the tax base

$$
\frac{\partial(\text { Tax base } / G D P)}{\partial(F D I / G D P)}=0.1930-0.6275 \times E A T R
$$

This means that FDI does not add anything to the tax base and even reduces it above a tax rate of $30 \%$. Whereas Germany is predicted to lose tax base on average with its EATR tax rates of 0.32 (in 2005), the UK and France gain with tax rates at 0.24 and 0.25 . The US (0.29) taxbase is virtually unaffected by FDI.

Columns 4 to 7 include some robustness checks. In column 4 , we repeat the regression without the corporate value added of which we only have data for a limited number of countries and periods. The number of observations is increased to 283. The results remain stable, though. In column 4 we use the statutory tax rate as a control variable and as interaction variable. The results are qualitatively the same; the statutory tax rate at which the contribution of FDI to the tax base becomes zero is equal to $36 \%$. Germany and the USA are above this level, the UK and France are beneath.

In columns 6 and 7, tax revenues are used as a dependent variable and are regressed, and the tax variable is the EATR and the statutory tax rate, respectively. The results are qualitatively and quantitatively very similar. The tax indicators at which FDI does not contribute to tax revenues anymore is $29.6 \%$ and $36.6 \%$, respectively.

\section{$5 \quad$ Discussion and concluding remarks}

The main contribution of this paper is to relax the assumption that foreign direct investment of multinational firms only affects profits at the investment location itself. We introduce investment projects that yield profit changes at the investment and the investor's location. Therefore, the marginal profit level at the investment location does not need to be equal to the cost of capital as defined in the usual way. Depending on the profit change at the investor's location, it can be higher or 
lower.

Our analysis implies that there is a dimension of capital flows which is largely neglected by the standard model: the quality dimension. With negative local profits generated by marginal projects, higher inbound investment may reduce the domestic tax base. This is confirmed by the evidence presented in this paper. Using aggregate investment and tax revenue data, we find that, on average, hightax countries lose tax revenue in response to incoming FDI while low-tax countries gain tax revenue. We calculate a break-even effective average tax rate of 30 per cent at which the contribution of an additional unit of FDI has a zero impact on tax revenues. Above this rate, incoming FDI decreases tax revenues.

The idea that higher taxes reduce the tax base is familiar from studies on tax induced profit shifting. These studies argue that firms react to international tax differences by shifting book profits from high tax countries to low tax countries by means of transfer pricing or intra firm debt contracts, so that reported profits are lower in high tax countries. Our theory, in contrast, explains these differences as a result of tax induced project selection. This does not stand in direct opposition to the profit shifting story, it rather offers a complementary explanation. However, accounting for project selection, as opposed to profit shifting, may have important consequences for empirical estimations on the one hand and policy recommendations on the other hand.

Firstly, a large part of the empirical literature on profit shifting starts from the observation that profitability is higher in low-tax affiliates than in high-tax affiliates. These tax-related differences are interpreted as a result of profit shifting, see e.g. Grubert \& Mutti (1991), Hines \& Rice (1994), Huizinga \& Laeven (2007) and Weichenrieder (2007). Accounting for project selection as an alternative explanation suggests that associating all tax-related profitability differences solely with profit shifting activities will overestimate its importance. Project selection therefore is a possible explanation for the puzzle that international profit shifting is large when measured through cross-country profitability differences, as in Huizinga \& Laeven (2007), but small when the use of profit shifting instruments is considered. E.g., Laeven, Nicodème \& Huizinga (2007) and Buettner \& Wamser (2007) show that taxes only have a small impact on the use of intra-firm loans, and tax practitioners report that the use of transfer pricing is substantially limited 
by legal provisions of the high-tax countries.

Clearly, the empirical analysis presented in the paper does not provide evidence in favour of project selection as opposed to profit shifting. Even though it would be highly desirable, it seems hard to test empirically which part of the tax driven profitability differences is due to profit shifting and which part is explained by real economic effects.

Secondly, when it comes to policy implications, it is important to know whether profitability differences are due to profit shifting or project selection. If we interpret all tax induced profitability differences as a result of profit shifting, it is natural to conclude that anti tax avoidance measures like e.g. transfer pricing documentation requirements or thin capitalization rules may increase corporate tax revenues. But if the composition effect partly explains these differences, the revenue raising potential of measures directed against the shifting of book profits is overestimated. Given that these policies may imply substantial costs and distortions of firm behavior, a misinterpretation of the data may lead to unnecessary welfare losses.

Another important implication of our analysis is that, if marginal profits are allowed to be negative, then the effects of tax changes on the quantity of investment can be reversed: Higher taxes may attract more investment, lower taxes may deter investment. From 1990 to 2000, Germany increased its stock of foreign held capital by about $520 \%$ (source: OECD) and performed much better in attracting foreign FDI than the UK (115\%), France (205\%), the US (180\%) or Japan (410\%). The standard way of reading these figures is that Germany attracted FDI despite its relatively high tax rates (before the tax reform in 2001, the corporate tax rates in Germany were between $52 \%$ and $58 \%$ and thus among the highest throughout the developed world). Our model provides an argument for a different interpretation: It could be that Germany attracted as much FDI because of its high tax rates.

A broader issue raised by our analysis is that, from the perspective of a host country, not every kind of inbound FDI is desirable. The quality dimension emphasized in our model suggests that there might be "good" types of inbound investment projects (those which increase production, employment and tax payments) and "bad" types (those which decrease activity and tax payments). Our model thus makes a first step towards providing a rationale for the skepticism to- 
wards certain types of foreign inbound investment which has always been present in the public debate.

Our model shows that more inbound investment can lead to smaller domestic tax bases. This may explain why inbound investment - especially in the form of $\mathrm{m} \& \mathrm{a}$ - is often regarded as not very attractive from the public point of view. But our model also shows that high taxes attract this kind of harmful investment projects. Thus, if our model captures some aspects of the real world, then tax policy makers should not promise more investment inflows in response to a possible tax cut but different investment inflows.

\section{Appendix}

This appendix derives equations (19) and (20). The partial derivative of welfare with respect to $\tau$ is given by

$$
\frac{\partial W}{\partial \tau}=\left(H^{\prime}-1\right) \int_{\Delta^{-}}^{\Delta^{+}} \int_{\Phi^{* c}}^{\Phi^{*+}} \Delta d \Phi^{*} d \Delta-\rho \int_{\Delta^{-}}^{\Delta^{+}} \frac{\Delta}{1-\tau^{*}} d \Delta-\tau H^{\prime}\left[\int_{\Delta^{-}}^{\Delta^{+}} \frac{\Delta}{1-\tau^{*}} \Delta d \Delta\right]
$$

where we have used $\frac{\partial \Phi^{* c}}{\partial \tau}=\frac{\Delta}{1-\tau^{*}}$. Taking the change in the price of capital into account, the total tax effect is $\frac{d W}{d \tau}=W_{\tau}+W_{\rho} \rho_{\tau}$. Where as $\rho_{\tau}$ is given in the text in equation (6), $W_{\rho}$ is equal to

$$
\frac{W}{\rho}=-\frac{\rho}{1-\tau^{*}}-H^{\prime} \frac{\tau}{1-\tau^{*}} \int_{\Delta^{-}}^{\Delta^{+}} \Delta d \Delta
$$

using $\frac{\partial \Phi^{* c}}{\partial \rho}=\frac{1}{1-\tau^{*}}$. It follows that $\frac{d W}{d \tau}$ can be expressed as

$$
\frac{d W}{d \tau}=\left(H^{\prime}-1\right) \int_{\Delta^{-}}^{\Delta^{+}} \int_{\Phi^{* c}}^{\Phi^{*+}} \Delta d \Phi^{*} d \Delta-\frac{\tau}{1-\tau^{*}} H^{\prime}\left[\int_{\Delta^{-}}^{\Delta^{+}} \Delta^{2} d \Delta-\left(\int_{\Delta^{-}}^{\Delta^{+}} \Delta d \Delta\right)^{2}\right]
$$

Now, consider the partial derivative of $W$ with respect to the foreign tax rate 
$\tau^{*}:$

$\frac{\partial W}{\partial \tau^{*}}=-\int_{\Delta^{-}}^{\Delta^{+}} \int_{\Phi^{* c}}^{\Phi^{*+}}\left[\Phi^{*}\right] d \Phi^{*} d \Delta-\rho \int_{\Delta^{-}}^{\Delta^{+}} \frac{\Phi^{* c}}{1-\tau^{*}} d \Delta-H^{\prime}\left[\tau \int_{\Delta^{-}}^{\Delta^{+}} \frac{\Phi^{* c}}{1-\tau^{*}} \Delta d \Delta\right]$

where we used $\frac{\partial \Phi^{* c}}{\partial \tau^{*}}=\frac{\Phi^{* c}}{1-\tau^{*}}$. Again, the total tax effect is equal to $\frac{d W}{d \tau^{*}}=$ $W_{\tau^{*}}+W_{\rho} \rho_{\tau^{*}}$ or

$\frac{d W}{d \tau^{*}}=-\int_{\Delta^{-}}^{\Delta^{+}} \int_{\Phi^{* c}}^{\Phi^{*+}} \Phi^{*} d \Phi^{*} d \Delta-H^{\prime} \frac{\tau}{1-\tau^{*}}\left[\int_{\Delta^{-}}^{\Delta^{+}} \Phi^{* c} \Delta d \Delta-\int_{\Delta^{-}}^{\Delta^{+}} \Delta d \Delta \int_{\Delta^{-}}^{\Delta^{+}} \Phi^{* c} d \Delta\right]$

\section{References}

Andrade, G., Mitchell, M. \& Stafford, E. (2001). New Evidence and Perspectives on Mergers, Journal of Economic Perspectives 15(2): 103-120.

Buettner, T. \& Wamser, G. (2007). Intercompany Loans and Profit Shifting Evidence from Company-Level Data, CESifo Working Paper No. 1959.

Castellani, D. \& Barba Navaretti, G. (2004). Investments Abroad and Performance at Home: Evidence from Italian Multinationals, CEPR Discussion Paper No. 4284 .

Desai, M. A., Foley, C. F. \& Hines, J. R. (2005a). Foreign Direct Investment and the Domestic Capital Stock, American Economic Review 95(2): 33-38.

Desai, M. A., Foley, C. F. \& Hines, J. R. (2005b). Foreign Direct Investment and the Domestic Economic Activity, NBER Working Paper Series 11075.

Devereux, M. P. (2006). The Impact of Taxation on the Location of Capital, Firms and Profit: A Survey of Empirical Evidence, Working Paper .

Devereux, M. P., Griffith, R. \& Klemm, A. (2002). Corporate Income Tax Reforms and International Tax Competition, Economic Policy 17(2): 450-493.

Egger, P. \& Pfaffermayer, M. (2003). The Counterfactual to Investing Abroad: An Endogenous Treatment Approach of Foreign Affiliate Activity, University of Innsbruck Working Papers in Economics No. 2003-2. 
Fuest, C., Huber, B. \& Mintz, J. (2005). Capital Mobility and Tax Competition, Foundations and Trends in Microeconomics 1(1): 1-62.

Grubert, H. \& Mutti, J. H. (1991). Taxes, Tariffs and Transfer Pricing in Multinational Corporate Decision Making, Review of Economics and Statistics 73: $285-293$.

Haufler, A. (2001). Taxation in a Global Economy, Cambridge University Press, Cambridge.

Hines, J. R. \& Rice, E. M. (1994). Fiscal Paradise: Foreign Tax Havens and American Business, Quarterly Journal of Economics 109(1): 149-182.

Huizinga, H. \& Laeven, L. (2007). International Profit Shifting Within European Multinationals, CEPR Working Paper No. 6048.

Huizinga, H. \& Nielsen, S. B. (1997). Capital Income and Profit Taxation with Foreign Ownership of Firms, Journal of International Economics 42: 149-165.

Jaeckle, R. (2006). Going Multinational: What Are the Effects on Home Market Performance?, Bundesbank Discussion Paper No. 3-2006 .

KPMG (2006). Corporate Tax Rate Survey.

Laeven, L., Nicodème, G. \& Huizinga, H. (2007). Capital Structure and International Debt Shifting, IMF Working Papers: 07/39 .

Markusen, J. R. (2002). Multinational Firms and the Theory of International Trade, Massachussets Institute of Technology, Cambridge, USA.

McGuckin, R. \& Nguyen, S. (1995). On Productivity and Plant Ownership Change - New Evidence from the Longitudinal Research Database, Rand Journal of Economics 26(2): 257-276.

Weichenrieder, A. J. (2007). Profit Shifting in the EU: Evidence from Germany, CESifo Working Paper No. 2043.

Wilson, J. D. \& Wildasin, D. E. (2004). Capital Tax Competition: Bane or Boon, Journal of Public Economics, Special Issue 88(6): 1065-91. 


\section{CESifo Working Paper Series}

for full list see www.cesifo-group.org/wp

(address: Poschingerstr. 5, 81679 Munich, Germany, office@cesifo.de)

2064 Jan Hanousek, Dana Hajkova and Randall K. Filer, A Rise by Any Other Name? Sensitivity of Growth Regressions to Data Source, July 2007

2065 Yin-Wong Cheung and Xing Wang Qian, Hoarding of International Reserves: Mrs Machlup’s Wardrobe and the Joneses, July 2007

2066 Sheilagh Ogilvie, 'Whatever Is, Is Right'?, Economic Institutions in Pre-Industrial Europe (Tawney Lecture 2006), August 2007

2067 Floriana Cerniglia and Laura Pagani, The European Union and the Member States: Which Level of Government Should Do what? An Empirical Analysis of Europeans' Preferences, August 2007

2068 Alessandro Balestrino and Cinzia Ciardi, Social Norms, Cognitive Dissonance and the Timing of Marriage, August 2007

2069 Massimo Bordignon, Exit and Voice. Yardstick versus Fiscal Competition across Governments, August 2007

2070 Emily Blanchard and Gerald Willmann, Political Stasis or Protectionist Rut? Policy Mechanisms for Trade Reform in a Democracy, August 2007

2071 Maarten Bosker and Harry Garretsen, Trade Costs, Market Access and Economic Geography: Why the Empirical Specification of Trade Costs Matters, August 2007

2072 Marco Runkel and Guttorm Schjelderup, The Choice of Apportionment Factors under Formula Apportionment, August 2007

2073 Jay Pil Choi, Tying in Two-Sided Markets with Multi-Homing, August 2007

2074 Marcella Nicolini, Institutions and Offshoring Decision, August 2007

2075 Rainer Niemann, The Impact of Tax Uncertainty on Irreversible Investment, August 2007

2076 Nikitas Konstantinidis, Gradualism and Uncertainty in International Union Formation, August 2007

2077 Maria Bas and Ivan Ledezma, Market Access and the Evolution of within Plant Productivity in Chile, August 2007

2078 Friedrich Breyer and Stefan Hupfeld, On the Fairness of Early Retirement Provisions, August 2007 
2079 Scott Alan Carson, Black and White Labor Market Outcomes in the $19^{\text {th }}$ Century American South, August 2007

2080 Christian Bauer, Paul De Grauwe and Stefan Reitz, Exchange Rates Dynamics in a Target Zone - A Heterogeneous Expectations Approach, August 2007

2081 Ana Rute Cardoso, Miguel Portela, Carla Sá and Fernando Alexandre, Demand for Higher Education Programs: The Impact of the Bologna Process, August 2007

2082 Christian Hopp and Axel Dreher, Do Differences in Institutional and Legal Environments Explain Cross-Country Variations in IPO Underpricing?, August 2007

2083 Hans-Werner Sinn, Pareto Optimality in the Extraction of Fossil Fuels and the Greenhouse Effect: A Note, August 2007

2084 Robert Fenge, Maximilian von Ehrlich and Matthias Wrede, Fiscal Competition, Convergence and Agglomeration, August 2007

2085 Volker Nitsch, Die Another Day: Duration in German Import Trade, August 2007

2086 Kam Ki Tang and Jie Zhang, Morbidity, Mortality, Health Expenditures and Annuitization, August 2007

2087 Hans-Werner Sinn, Public Policies against Global Warming, August 2007

2088 Arti Grover, International Outsourcing and the Supply Side Productivity Determinants, September 2007

2089 M. Alejandra Cattaneo and Stefan C. Wolter, Are the Elderly a Threat to Educational Expenditures?, September 2007

2090 Ted Bergstrom, Rod Garratt and Damien Sheehan-Connor, One Chance in a Million: Altruism and the Bone Marrow Registry, September 2007

2091 Geraldo Cerqueiro, Hans Degryse and Steven Ongena, Rules versus Discretion in Loan Rate Setting, September 2007

2092 Henrik Jacobsen Kleven, Claus Thustrup Kreiner and Emmanuel Saez, The Optimal Income Taxation of Couples as a Multi-Dimensional Screening Problem, September 2007

2093 Michael Rauber and Heinrich W. Ursprung, Life Cycle and Cohort Productivity in Economic Research: The Case of Germany, September 2007

2094 David B. Audretsch, Oliver Falck and Stephan Heblich, It's All in Marshall: The Impact of External Economies on Regional Dynamics, September 2007

2095 Michael Binder and Christian J. Offermanns, International Investment Positions and Exchange Rate Dynamics: A Dynamic Panel Analysis, September 2007 
2096 Louis N. Christofides and Amy Chen Peng, Real Wage Chronologies, September 2007

2097 Martin Kolmar and Andreas Wagener, Tax Competition with Formula Apportionment: The Interaction between Tax Base and Sharing Mechanism, September 2007

2098 Daniela Treutlein, What actually Happens to EU Directives in the Member States? - A Cross-Country Cross-Sector View on National Transposition Instruments, September 2007

2099 Emmanuel C. Mamatzakis, An Analysis of the Impact of Public Infrastructure on Productivity Performance of Mexican Industry, September 2007

2100 Gunther Schnabl and Andreas Hoffmann, Monetary Policy, Vagabonding Liquidity and Bursting Bubbles in New and Emerging Markets - An Overinvestment View, September 2007

2101 Panu Poutvaara, The Expansion of Higher Education and Time-Consistent Taxation, September 2007

2102 Marko Koethenbuerger and Ben Lockwood, Does Tax Competition Really Promote Growth?, September 2007

2103 M. Hashem Pesaran and Elisa Tosetti, Large Panels with Common Factors and Spatial Correlations, September 2007

2104 Laszlo Goerke and Marco Runkel, Tax Evasion and Competition, September 2007

2105 Scott Alan Carson, Slave Prices, Geography and Insolation in $19^{\text {th }}$ Century AfricanAmerican Stature, September 2007

2106 Wolfram F. Richter, Efficient Tax Policy Ranks Education Higher than Saving, October 2007

2107 Jarko Fidrmuc and Roman Horváth, Volatility of Exchange Rates in Selected New EU Members: Evidence from Daily Data, October 2007

2108 Torben M. Andersen and Michael Svarer, Flexicurity - Labour Market Performance in Denmark, October 2007

2109 Jonathan P. Thomas and Tim Worrall, Limited Commitment Models of the Labor Market, October 2007

2110 Carlos Pestana Barros, Guglielmo Maria Caporale and Luis A. Gil-Alana, Identification of Segments of European Banks with a Latent Class Frontier Model, October 2007

2111 Felicitas Nowak-Lehmann D., Sebastian Vollmer and Immaculada Martínez-Zarzoso, Competitiveness - A Comparison of China and Mexico, October 2007

2112 Mark Mink, Jan P.A.M. Jacobs and Jakob de Haan, Measuring Synchronicity and Comovement of Business Cycles with an Application to the Euro Area, October 2007 
2113 Ossip Hühnerbein and Tobias Seidel, Intra-regional Tax Competition and Economic Geography, October 2007

2114 Christian Keuschnigg, Exports, Foreign Direct Investment and the Costs of Corporate Taxation, October 2007

2115 Werner Bönte, Oliver Falck and Stephan Heblich, Demography and Innovative Entrepreneurship, October 2007

2116 Katrin Assenmacher-Wesche and M. Hashem Pesaran, Assessing Forecast Uncertainties in a VECX Model for Switzerland: An Exercise in Forecast Combination across Models and Observation Windows, October 2007

2117 Ben Lockwood, Voting, Lobbying, and the Decentralization Theorem, October 2007

2118 Andrea Ichino, Guido Schwerdt, Rudolf Winter-Ebmer and Josef Zweimüller, Too Old to Work, too Young to Retire?, October 2007

2119 Wolfgang Eggert, Tim Krieger and Volker Meier, Education, Unemployment and Migration, October 2007

2120 Stefan Napel and Mika Widgrén, The European Commission - Appointment, Preferences, and Institutional Relations, October 2007

2121 Bertil Holmlund and Martin Söderström, Estimating Income Responses to Tax Changes: A Dynamic Panel Data Approach, October 2007

2122 Doina Maria Radulescu, From Separate Accounting to Formula Apportionment: Analysis in a Dynamic Framework, October 2007

2123 Jelle Brouwer, Richard Paap and Jean-Marie Viaene, The Trade and FDI Effects of EMU Enlargement, October 2007

2124 Kurt R. Brekke, Luigi Siciliani and Odd Rune Straume, Competition and Waiting Times in Hospital Markets, October 2007

2125 Alexis Direr, Flexible Life Annuities, October 2007

2126 Johannes Becker and Clemens Fuest, Quality versus Quantity - The Composition Effect of Corporate Taxation on Foreign Direct Investment, October 2007 